\title{
DEVELOPMENT OF PRE-SERVICE FOREIGN LANGUAGES TEACHERS' EMOTIONAL INTELLIGENCE BY MEANS OF REFLECTION
}

\author{
Iryna Zadorozhna \\ Ternopil Volodymyr Hnatiuk National Pedagogical University, Ternopil, Ukraine \\ irynazadorozhnai@gmail.com \\ Olha Datskiv \\ Ternopil Volodymyr Hnatiuk National Pedagogical University, Ternopil, Ukraine \\ olhadatskiv@gmail.com \\ Natalia Levchyk \\ Ternopil Volodymyr Hnatiuk National Pedagogical University, Ternopil, Ukraine \\ natkalev777@gmail.com
}

\begin{abstract}
The purpose of this paper is to investigate the development of pre-service foreign languages teachers' emotional intelligence by means of reflection. 70 students of Ternopil Volodymyr Hnatiuk National Pedagogical University, Department of Foreign Languages, participated in the study for four years. Among them, there were 67 females and 3 males aged 18 to 26 . Research instruments used in the study are Self-Rated Emotional Intelligence Scale and Reflection in Learning Scale. Following the completion of these self-rated questionnaires in the first semester of their programme, the participants were engaged in reflective practice by means of three reflective tools - writing journals, reflective portfolios and reflective classroom discussions. Five domains of emotional intelligence (perceiving, using, understanding, managing emotions and social management) became an integral part of reflection. It was hypothesised that a relationship between emotional intelligence and reflective practice would emerge. At the end of the eighth semester, the participants self-assessed their emotional intelligence and reflective skills again using the same instruments. Results indicate that systematic reflection develops pre-service foreign languages teachers' emotional intelligence. In addition, classroom discussions revealed the need for reflection in a foreign language for personal and professional development of the participants. We conclude that there is a relationship between the level of pre-service foreign languages teachers' emotional intelligence and the development of their reflective skills. The findings of the study can be applied in the design and implementation of educational programmes for pre-service foreign languages teachers.
\end{abstract}

Keywords: pre-service foreign languages teachers; emotional intelligence; reflection; emotions; writing journal; reflective portfolio; reflective classroom discussion.

\section{Introduction}

The development of humanistic pedagogy in Ukrainian education, its integration in the world educational process, profound change in our society caused by internalisation and globalisation of world economy call for new approaches in the process of in-service foreign languages teachers' education and training for they are regarded as agents of change by Ukrainian society. A learner-centred approach in professional education requires the formation of a clearly defined set of both language and professional competences and for the development of students' cognitive abilities and psychological qualities which underlie and optimise an intercultural communication (Saienko, 2017, p.4). This approach is especially relevant for professionals in the field of foreign languages learning and teaching who will enable and facilitate this communication. Thus, the importance of development of pre-service foreign languages teachers' emotional intelligence as an integral component of their professional competence is hard to overestimate.

Emotional intelligence is defined by Goleman (1996) as "understanding one's own feelings, empathy for the feelings of others and the regulation of emotion in a way that enhances living" (p.4). As such, the concept of emotional intelligence is inseparably connected with reflection. Mayer and Salovey's (1990) definition of emotional intelligence as "the capacity to reason about emotions to enhance thinking. ... the abilities to accurately perceive emotions, to access and generate emotions to assist thought, to understand emotions and emotional knowledge, and to reflectively regulate emotions so as to promote emotional and intellectual growth" (p. 187) further prove the link between emotional intelligence and reflection.

Different aspects of the problem of foreign languages teachers and students' emotional intelligence have been researched lately: the relationship between English teachers' level of emotional intelligence and their assessment by the students (Barłożek, 2015), the relationship between emotional intelligence, language learning strategies and English proficiency among EFL (English as Foreign Language) university students (Zarafshan \& Areshiri, 2012), possible relationship between perceptions of emotional intelligence and 
attitudes towards foreign language learning among university students majoring in English as a foreign language (Oz, Demirezen \& Pourfeiz, 2015).

Likewise, different aspects of reflective learning and teaching of foreign languages have been investigated: the roots of reflective practice in foreign language teaching (Quesada Pacheco, 2005), second language learning skills development (Chau \& Cheng, 2012), reflective journals (Thorpe, 2004).

Several studies explore the affective domain through the reflection in tutorial settings (Gill, 2014) and in teacher preparation (Shoffner, 2009). However, a relationship between the development of pre-service foreign languages teachers' emotional intelligence and development of their reflection skills and ways of pre-service foreign teachers' emotional intelligence development by means of reflection need further research. The research questions for this study are as follows:

1) Is it possible to develop pre-service foreign teachers' emotional intelligence by means of systematic reflection in the process of education?

2) Is it possible to incorporate practices which support emotional intelligence development in educational programmes for pre-service foreign languages teachers?

The aim of this paper is to investigate the development of pre-service foreign languages teachers' emotional intelligence by means of reflection. The tasks set in the study are to define the structure and characteristics of emotional intelligence and reflection, to show the relationship between the development of pre-service foreign languages teachers' emotional intelligence and their reflection skills, to specify the ways of future English teachers' emotional intelligence development by means of reflection.

\section{Method}

In 2014-2018 academic years, a study which measured the relationship between pre-service foreign languages teachers' emotional intelligence and reflective skills development was conducted. The aim of the study was to find out whether there was dynamics in the level of emotional intelligence caused by engagement of pre-service foreign languages teachers' in reflective practices, such as participation in classroom discussions, including reflective entries in their writing journals and reflective portfolios as Practical English Course requirements.

\section{Participants}

70 Foreign Languages Department students of Ternopil Volodymyr Hnatiuk National Pedagogical University - pre-service foreign languages teachers participated in the study. Among them, there were 67 females and 3 males aged between 18 and 26 years old.

\section{Instruments}

Separate tools were used to measure the participants' emotional intelligence and reflective skills: The Self-Rated Emotional Intelligence Scale (Brackett, Rivers, Shiffman, Lerner, \& Salovey, 2006) and The Reflection in Learning Scale (Sobral, 2001). The tools have been tested for reliability and validity and are recommended for use in educational settings.

\section{The Self-Rated Emotional Intelligence Scale (SREIS)}

Emotional intelligence was measured using The Self-Rated Emotional Intelligence Scale which is recognised as a valid and reliable instrument (Brackett, Rivers, Shiffman, Lerner, \& Salovey, 2006). The scale consists of 19 items, determines emotional intelligence in four domains ( $\mathrm{P}$ - Perceiving Emotion and U - Use of Emotion; R - Understanding Emotion; M1 - Managing Emotion (self); M2 - Social Management), contains questions which are answered on a five-point Likert scale (1 - "very inaccurate", 2 "moderately inaccurate", 3 - "neither inaccurate nor accurate", 4 - "moderately accurate", 5 - "very accurate"). The Self-Rated Emotional Intelligence Scale takes approximately 10 minutes to complete. Higher scores indicate a higher level of emotional intelligence. The assessment gives numerical results on each domain as well as a general score of emotional intelligence (For the Self-Rated Emotional Intelligence Scale see Appendix A.). Items 2, 4, 15, 16 are reverse scored. The participants' ratings of individual questionnaire items are added up in order to calculate their total score for emotional intelligence.

\section{The Reflection in Learning Scale (RLS)}

The Reflection in Learning Scale (Sobral, 2001) is a self-report questionnaire to evaluate reflection in learning. The instrument comprises 14 items, and, in addition, includes a four-point global scale for assessing the personal efficacy of the reflection on learning. The extent of perceived personal efficacy ranged from restricted to maximal. The main scale was measured using a 7 -point scale $(1=$ never; $7=$ always $)$ assessing the degree to which the respondents use reflection in learning. Although the RLS Scale was initially used in 
medical education (dentistry), a research study (Kalk, Luik, Taimalu \& Täht, 2014) showed that this scale is suitable for use in different disciplines in teacher education (For the Reflection in Learning Scale see Appendix B.).

\section{Procedure}

The study commenced at the beginning of academic year 2014-2015. The researchers met with potential participants and outlined the study in a presentation about emotional intelligence and reflection. 70 first year students expressed their consent to participate in the study. SREIS and RLS questionnaires were administered with permission from Ternopil Volodymyr Hnatiuk National Pedagogical University administration and lecturers and completed by the respondents in class in the first semester (2014) and in the eighth semester (2018). The response rate was $100 \%$ and $97 \%$ accordingly. The data was analysed using Microsoft Excel 2010. As the programme progressed, students were systematically involved in end-of-class discussions about their learning experiences, once a month wrote reflective entries in writing journals and worked on a reflective portfolio as a part of the ongoing assessment in their Practical English course.

\section{Results}

The participating students' ratings of individual questionnaire items were added up in order to calculate their total scores for emotional intelligence and reflective skills at the beginning and at the end of the study. The findings showed that overall the participants reported high levels of emotional intelligence and reflective skills. The descriptive statistics are summarised in Tables 1 and 2.

\section{Levels of emotional intelligence at the beginning and at the end of the study}

Table 1

\begin{tabular}{|l|l|l|l|l|l|}
\hline Variable & $\mathrm{N}$ & Mean & Minimum & Maximum & SD \\
\hline $\begin{array}{l}\text { Emotional intelligence levels at the } \\
\text { beginning of the study }\end{array}$ & 70 & 61.62 & 43 & 79 & 9.59 \\
\hline $\begin{array}{l}\text { Emotional intelligence levels at the } \\
\text { end of the study }\end{array}$ & 70 & 74.46 & 61 & 90 & 8.05 \\
\hline
\end{tabular}

Levels of participants' reflective skills at the beginning and at the end of the study

Table 2

\begin{tabular}{|l|l|l|l|l|l|}
\hline Variable & $\mathrm{N}$ & Mean & Minimum & Maximum & SD \\
\hline $\begin{array}{l}\text { Reflective skills levels at the } \\
\text { beginning of the study }\end{array}$ & 70 & 62.27 & 44 & 81 & 10.59 \\
\hline $\begin{array}{l}\text { Reflective skills levels at the end of } \\
\text { the study }\end{array}$ & 70 & 73.51 & 48 & 94 & 11.52 \\
\hline
\end{tabular}

The results indicate an increase in levels of emotional intelligence and reflective skills. The average percentage increase is shown in Table 3.

Average percentage increase of emotional intelligence and reflective skills

Table 3

\begin{tabular}{|l|l|}
\hline Variable & Percentage increase between measures \\
\hline Emotional intelligence levels & $21 \%$ \\
\hline Reflective skills levels & $18 \%$ \\
\hline
\end{tabular}

\section{Discussion}

The purpose of this paper was to investigate the development of pre-service foreign languages teachers' emotional intelligence by means of reflection. The discussion will focus on the relationship between the level of pre-service foreign languages teachers' emotional intelligence and the development of their reflective skills. Recommendations will be given regarding reflective tools used to develop pre-service foreign languages teachers' emotional intelligence. Limitations of this study will be outlined, applications of the research will be suggested. 
Reflective practice allows learners to become aware of their emotions, recognise their individual needs and develop strategies to regulate thinking. It is equally important to increase students' ability to solve problems and promote independent critical thinking. Therefore, higher educational institutions preparing foreign languages teachers are required to employ emotive regulatory practices. A key construct that can align closely with emotive regulatory practices is emotional intelligence.

Goleman (2000) identifies five "domains" of emotional intelligence: knowing emotions (selfawareness), managing emotions, motivating oneself (self-management), recognising and understanding other people's emotions (social awareness), managing emotions of others (relationship management). Further developing the concept of emotional intelligence Goleman explores the relation between performance at work, dealing with others, conduct and outlines a model of emotional intelligence adopted from P. Salovey and J. Mayer which consists of five basic emotional and social competences: self-awareness, self-regulation, motivation, empathy, social skills (Goleman, 2000). Reflection is considered to be a mental process that facilitates the transformation of experience into personal knowledge and creates the connection between the emotional and cognitive states (Boyd, 1983). The use of reflective tools in this study enabled the development of five domains of emotional intelligence (perceiving, using, understanding, managing emotions and social management).

Dewey stated that reflecting practice helps people to learn more than from just experience. Thus, reflection is goal oriented and controlled by the learner (Chau \& Cheng, 2012, p. 17). It involves selfassessment and may lead to goal revision as learners can set different targets thinking on their achievements and failures. The fact that Dewey considered reflection to be language-specific (Chau \& Cheng, 2012, p.17) is especially important for pre-service foreign languages teachers as they should be encouraged not only to reflect on the results of their language learning but also to reflect using the foreign language (languages) (Zadorozhna, 2017, p. 8).

Boyd and Fales (1983) view reflective learning as "a process of internally examining and exploring an issue of concern, triggered by an experience, which creates and clarifies meaning in terms of self, and which results in a changed conceptual perspective" (p. 99). According to Jones and Shelton (2006) reflection "brings into conscious awareness one's motivations, thoughts, beliefs... and expectations for the purpose of gaining insightful understanding as to their meaning, their connections to what is personally known, and in light of new experiences and information. Reflection makes possible the insights necessary to learn from experience and alter habitual behaviours" (p. 53).

Researchers view reflection as a mental process which makes students concentrate on the analysis of their experience, motivation, purposes with the aim of understanding them better and results in change of behaviour. Reflective skills, therefore, can be described as their ability to analyse individual needs and goals of learning a foreign language; determine individual level of language proficiency; set individual goals; determine difficulties of learning a foreign language; analyse individual techniques and strategies; assess the result and its correspondence to the determined target; analyse the relevance of the strategies used to the purpose and the result; determine the reasons for failure; look at the problem from different perspectives, refocus the experience; think over alternative strategies; analyse external influences, implications of the experience in the context of future applications; make a comparative analysis of the ways of solution (Zadorozhna, 2017, p. 9).

The emotive constituent of reflection is not overlooked in research, particularly in different reflection models. In this study, classroom discussions utilised Gibbs' model of reflection which contains six stages: description, feelings, evaluation, analysis, conclusion and action plan (Gibbs, 1988).

The study shows that pre-service foreign languages teachers can benefit from the introduction of diverse reflection tools into their training. Reflection can help learners develop their emotional intelligence if they include a consideration of feelings as a significant part of their reflections. This conclusion is consistent with research findings that systematic reflection helps to understand one's behaviour better, promotes motivation and increases confidence and competence (Thorpe, 2004).

Teacher development is related to personal development, particularly personal development as a teacher. This process entails the teachers' personal choices about the way they think, feel and behave as teachers, and how teachers can become aware of the learning atmosphere they create and how the choices they make can affect the learning environment of their students. Unfortunately, this practice rarely occurs at different levels of teaching (elementary, high school, university) (Quesada Pacheco, 2005) despite the fact that there are different reflection tools to develop pre-service foreign languages teachers' emotional intelligence. If the reflection is to become systematic, it has to be included at different levels of teaching and learning.

Besides those used in this study, there are many other reflection tools to develop pre-service foreign language teachers' emotional intelligence. Students' diaries, in particular, allow teachers to collect data from the learners when developing action research. Learners are affected by teaching, so getting feedback from 
them is productive. The valuable aspect of diaries is that students are writing about their feelings as they experience the language: if they liked the activities, how they felt (intimidated, stressed, anxious or happy, elated, relaxed). Teachers can obtain feedback through this observational technique and encourage further students' reflection. Other tools include interviews, essays, posting and comments in blogs, teaching portfolios. It is our responsibility as educators to incorporate those tools in our teaching.

Limitations within this study can be found in its design, namely the use of self-reported questionnaires which may be considered not valid enough by some researchers. These instruments were used to collect data and to raise pre-service foreign languages teachers' awareness of the need for systematic reflection which enhances their cognitive and affective abilities.

\section{Conclusions}

This research proved that there is a relationship between the development of pre-service foreign languages teachers' emotional intelligence and their reflection skills. Understanding their emotions and systematic reflection over own language enables students to become better learners and to develop emotional component of their professional competence. There is a strong need for creating learning conditions at tertiary education institutions in which individual and group reflection over emotions is facilitated and encouraged. Educational programmes for pre-service foreign languages teachers should be designed to help students develop their emotional intelligence and reflective skills.

\section{References:}

Barłożek, N. (2015). EFL Teachers’ Affective Competencies and Their Relationships with the Students. In Piechurska-Kuciel E., Szyszka M. (Eds), The Ecosystem of the Foreign Language Learner. Second Language Learning and Teaching (pp.97115). Switzerland, Cham: Springer International Publishing. https://doi.org/10.1007/978-3-319-14334-7_7

Brackett, M., Rivers S. et al. (2006) Relating Emotional Abilities to Social Functioning: A Comparison of Self-Report and Performance Measures of Emotional Intelligence. Journal of Personality and Social Psychology, 91(4), $780-795$. https://doi.org/10.1037/0022-3514.91.4.780

Boyd, E.M., \& Fales, A. W. (1983). Reflective learning: key to learning from experience. Journal of Humanistic Psychology, 23, 99117. https://doi.org/10.1177/0022167883232011

Chau, J., \& Cheng, G. (2012). Developing Chinese Students' Reflective Second Language Learning Skills in Higher Education. The Journal of Language Teaching and Learning, 2(1), 15-32.

Datskiv, O. (2017). Developing future English teachers’ emotional intelligence via dramatisation. Naukovi zapy ‘sky Ternopil`s `kogo nacional’nogo universy`tetu imeni Volody`my`ra Gnatyuka. Seriya: pedagogika, 4, 49-56. http://dx.doi.org/10.25128/24153605.17.4.7

Goleman, D. (1996). Emotional Intelligence: Why It Can Matter More than IQ. London: Bloomsbury.

Gill, G. (2014) The nature of reflective practice and emotional intelligence in tutorial settings. Journal of Education and Learning, 3 (1), 86-100. http://dx.doi.org/10.5539/jel.v3n1p86

Goleman, D. (2000). Working with Emotional Intelligence. New York, USA: Bantam Books.

Gibbs, G. (1988). Learning by doing: a guide to teaching and learning methods. London: Further Education Unit.

Zadorozhna, I. (2017). Reflective foreign language teaching and learning of university students. Naukovi zapy`sky Ternopil``kogo nacional`nogo universy`tetu imeni Volody`my`ra Gnatyuka. Seriya: pedagogika, 4, 6-12. http://dx.doi.org/10.25128/2415-3605.17.4.1

Quesada Pacheco, A. (2011). Reflective teaching and its impact on foreign language teaching. Actualidades Investigativas en Educación 5(3), 1-19. http://dx.doi.org/10.15517/aie.v5i3.9166

Kalk, K., Luik, P., Taimalu, M., \& Täht, K. (2014). Validity and Reliability of Two Instruments to Measure Reflection: A Confirmatory Study. Trames: A Journal of the Humanities and Social Sciences, 18(2), 121-134. http://dx.doi.org/10.3176/tr.2014.2.02

Mayer, J., \& Salovey, P. (1997). What is emotional intelligence? In P. Salovey, \& D. J. Sluyter (Eds.), Emotional development and emotional intelligence: Educational implications (pp.3-31). New York, NY. Basic Books.

Oz, H., Demirezen, M., \& Pourfeiz, J. (2015). Emotional Intelligence and Attitudes Towards Foreign Language Learning: Pursuit of Relevance and Implications. Procedia - Social and Behavioral Sciences, 186, 416-423. https://doi.org/10.1016/j.sbspro.2015.04.118

Saienko, N. (2017). Cognitive development of students in foreign language acquisition. Advanced Education, 7, 4-8. http://dx.doi.org/10.20535/2410-8286.77570

Shoffner, M. (2009). The place of personal: exploring the affective domain through reflection in teacher preparation. Teaching and Teacher Education, 25, 783-789. http://dx.doi.org/10.1016/j.tate.2008.11.012

Sobral, D. (2001). Medical students' reflection in learning in relation to approaches to study and academic achievement. Medical Teacher, 23(5), 508-513. http://dx.doi.org/10.1080/01421590126488

Thorpe, K. (2004) Reflective learning journals: from concept to practice. Reflective Practice, 5(3), 327-343. https://doi.org/10.1080/1462394042000270655

Zarafshan, M., Areshiri, M. (2012). The Relationship between Emotional Intelligence, Language Learning Strategies and English Proficiency among Iranian EFL University Students. Journal of Educational and Instructional Studies in the World, 2 (3), 105-114. 


\section{APPENDIX A.}

\section{Self-Rated Emotional Intelligence Scale (Brackett, Rivers, Shiffman, Lerner, \& Salovey, 2006)}

The following set of items pertains to your insight into emotions. Please use the rating scale below to describe how accurately each statement describes you. Describe yourself as you generally are now, not as you wish to be in the future. Describe yourself as you honestly see yourself, in relation to other people you know of the same sex as you are, and roughly your same age. Please read each statement carefully, and then circle the number that corresponds to how inaccurately or accurately each statement describes you.

1 - very inaccurate, 2 - moderately inaccurate, 3 - neither inaccurate nor accurate, 4 - moderately accurate, 5 - very accurate

\begin{tabular}{|c|c|c|c|}
\hline No. & Domain & Item Wording & Your Score \\
\hline 1 & $\mathrm{P}$ & $\begin{array}{l}\text { By looking at people's facial expressions, I recognize the emotions they are } \\
\text { experiencing. }\end{array}$ & 12345 \\
\hline 2 & $\mathrm{U}$ & I am a rational person and I rarely, if ever, consult my feelings to make a decision (r). & 12345 \\
\hline 3 & $\mathrm{R}$ & I have a rich vocabulary to describe my emotions. & 12345 \\
\hline 4 & M1 & I have problems dealing with my feelings of anger $(\mathrm{r})$ & 12345 \\
\hline 5 & M2 & $\begin{array}{l}\text { When someone I know is in a bad mood, I can help the person calm down and feel } \\
\text { better quickly. }\end{array}$ & 12345 \\
\hline 6 & $\mathrm{P}$ & I am aware of the nonverbal messages other people send. & 12345 \\
\hline 7 & $\mathrm{U}$ & When making decisions, I listen to my feelings to see if the decision feels right. & 12345 \\
\hline 8 & $\mathrm{R}$ & I could easily write a lot of synonyms for emotion words like happiness or sadness. & 12345 \\
\hline 9 & M1 & I can handle stressful situations without getting too nervous. & 12345 \\
\hline 10 & M2 & I know the strategies to make or improve other people's moods. & 12345 \\
\hline 11 & $\mathrm{P}$ & I can tell when a person is lying to me by looking at his or her facial expression. & 12345 \\
\hline 12 & $\mathrm{U}$ & I am a rational person and don't like to rely on my feelings to make decisions. & 12345 \\
\hline 13 & $\mathrm{R}$ & $\begin{array}{l}\text { I have the vocabulary to describe how most emotions progress from simple to complex } \\
\text { feelings. }\end{array}$ & 12345 \\
\hline 14 & M1 & I am able to handle most upsetting problems. & 12345 \\
\hline 15 & M2 & $\begin{array}{l}\text { I am not very good at helping others to feel better when they are feeling down or angry } \\
\text { (r). }\end{array}$ & 12345 \\
\hline 16 & $\mathrm{P}$ & My quick impressions of what people are feeling are usually wrong (r). & 12345 \\
\hline 17 & $\mathrm{R}$ & $\begin{array}{l}\text { My "feelings" vocabulary is probably better than most other persons' "feelings" } \\
\text { vocabularies. }\end{array}$ & 12345 \\
\hline 18 & M1 & I know how to keep calm in difficult or stressful situations. & 12345 \\
\hline 19 & M2 & $\begin{array}{l}\text { I am the type of person to whom others go when they need help with a difficult } \\
\text { situation. }\end{array}$ & 12345 \\
\hline
\end{tabular}

Note. $\mathrm{P}$ - Perceiving Emotion; U - Use of Emotion; (r) - reverse scored; R -Understanding Emotion; M1 - ManagingEmotion (self); M2 - Social Management. 


\section{APPENDIX B.}

\section{The Scale of Reflection-in-Learning (RLS) (Sobral, 2001)}

Please answer the items below in relation to your learning experiences in foreign language teaching programme. Draw a circle around the scale number closer to your usual behaviour.

To what extent have I: $(1=$ never, $2=$ very rarely, $3=$ sometimes, $4=$ when possible, $5=$ often, $6=$ when required, $7=$ always)

\begin{tabular}{|c|c|c|}
\hline No. & Item wording & Your score \\
\hline 1 & carefully planned my learning tasks in the course. & 1234567 \\
\hline 2 & talked with other students about learning and methods of study & 1234567 \\
\hline 3 & reviewed previously studied subjects during each time & 1234567 \\
\hline 4 & integrated all topics in a course with each other and with those of other courses & 1234567 \\
\hline 5 & $\begin{array}{l}\text { mentally processed what I already knew and what I needed to know about the topics or } \\
\text { procedures }\end{array}$ & 1234567 \\
\hline 6 & been aware of what I was learning and for what purposes & 1234567 \\
\hline 7 & $\begin{array}{l}\text { sought out interrelations between topics in order to construct more comprehensive notions } \\
\text { about some theme }\end{array}$ & 1234567 \\
\hline 8 & $\begin{array}{l}\text { pondered over the meaning of the things I was studying and learning in relation to my } \\
\text { personal experience }\end{array}$ & 1234567 \\
\hline 9 & $\begin{array}{l}\text { conscientiously sought to adapt myself to the varied demands of the different courses and } \\
\text { training activities }\end{array}$ & 1234567 \\
\hline 10 & $\begin{array}{l}\text { systematically reflected on how I was studying and learning in different contexts and } \\
\text { circumstances }\end{array}$ & 1234567 \\
\hline 11 & mindfully summarized what I was learning day in, day out, in my studies & 1234567 \\
\hline 12 & exerted my capacity to reflect during learning experience & 1234567 \\
\hline 13 & $\begin{array}{l}\text { diligently removed negative feelings in relations to aims, objectives, behaviours, topics or } \\
\text { problems pertaining to my studies }\end{array}$ & 1234567 \\
\hline 14 & constructively self-assessed my work as a learner & 1234567 \\
\hline
\end{tabular}

